\title{
THE EFFECT OF USING BLENDED LEARNING MODEL ON ENHANCING STUDENTS' SPEAKING SKILL IN SENIOR HIGH SCHOOLS
}

\author{
${ }^{1,2}$ Irma Dewi Isda, ${ }^{1}$ Purwati, \& ${ }^{\mathbf{1}}$ Imran \\ ${ }^{1}$ English Lecturer, Teachers and Sciences Faculty, Samudra University, Indonesia \\ ${ }^{2}$ Corresponding Author Email: irmaisda.fkip@unsam.ac.id
}

\begin{tabular}{|c|c|}
\hline Article Info & Abstract \\
\hline $\begin{array}{l}\text { Article History } \\
\text { Received: October } 2020 \\
\text { Revised: December } 2020 \\
\text { Published: January } 2021\end{array}$ & $\begin{array}{l}\text { This study aimed at investigating the effect of blended learning on the English- } \\
\text { students' speaking skills at SMAN } 2 \text { Patra Nusa Aceh Tamiang. Also, this study } \\
\text { investigated students' level differences of English-speaking skills of SMA Patra } \\
\text { Nusa students. Twenty-five students of the eleventh-grade class were involved in }\end{array}$ \\
\hline $\begin{array}{l}\text { Keywords } \\
\text { Blended learning; } \\
\text { Speaking skill; } \\
\text { Google classroom; }\end{array}$ & $\begin{array}{l}\text { this study. This study used a quasi-experimental with pre-experimental design. } \\
\text { The instruments used in this study were observation and test (pretest and posttest). } \\
\text { The results of data analysis showed that sig. } 2 \text {-tailed }=0.000<\alpha(0.05) \text {, it means } \\
\text { reject H0, accepted Ha. Finding obtained of pretest } 77,04 \text { and posttest } 88,95 \text {. In } \\
\text { conclusion, the mean pretest and posttest scores differ significantly. In other } \\
\text { words, blended learning positively affects students speaking skills used in the } \\
\text { media google classroom at SMA N } 2 \text { Patranusa. }\end{array}$ \\
\hline
\end{tabular}

How to cite: Isda, I. D. \& Imran. (2021). The Effect of Using Blended Learning Model on Enhancing Students' Speaking Skill in Senior High Schools, JOLLT Journal of Languages and Language Teaching, 9(1), 92-98. DOI: https://doi.org/10.33394/jollt.v\%vi\%i.2921

\section{INTRODUCTION}

In the industrial revolution 4.0 era, technology-assisted language learning has a vital role in EFL contexts. Learners are now more interested in learning using gadgets, smartphones, laptops, and androids (Abe, 2013). They can easily open google search, Youtube, Google play, and stores to access various kinds of information connected to the internet. Because of this, students are going to be easy to be involved in language activities to improve their language skills. In involving students in various language activities, English teachers should become communicative and active in using current EFL learning and teaching models. Many English teachers feel more comfortable accessing the internet as online learning by using blended learning (Sharma, 2010; Zilka \& Cohen, 2019).

Blended learning is becoming a hot topic of conversation in education, as more sophisticated technology affects the learning model (Limbong, 2017). Blended learning is faceto-face learning (traditional) method accompanied by online learning. It is often defined as a combination of face-to-face and online learning (Garrison, 2011). Also, it can be stated that half of the teaching-learning process can be done through media online.

The Blended learning model's application refers to Ginaya (2018) research, who has completed a study on implementing blended learning. It can improve students' speaking and writing proficiency of the third-semester students at the vocational college. The improvement achieved by the students here is also supported by the fact that the application of WebQuest active-learning activities can improve the students' learning motivation and interest. As a result, they can interact actively during the entire process of learning. Therefore, web-based activities in the classroom are really needed to maximize their English language skills.

Many researchers have done studies on blended learning using different online platform media. The researcher was interested in observed the English teaching and learning process in 
the senior high schools. Based on the observation, blended learning was done by some English teachers at the school, but it was not fully maximal. In addition, teachers taugh students with integrative skills. This study tried to employ the blended learning model for teaching speaking skills because speaking skills were considered the most difficult skills to practice. Students also faced some problems in teaching speaking skills, such as lack of fluency, vocabulary, pronunciation, and accuracy (Sumarsono, Muliani, \& Bagis, 2020). These make students feel anxious to speak in English (Ardiansyah, 2020; Hoesny, Cahyani, \& Azis, 2020). To minimize these challenges, English teachers employed the blended learning model.

Related to students' English speaking skills, students learn best when they have an attractive model in the teaching-learning process (Maryam, 2020). Thus, blended learning is as an alternative to training students to practice speaking in the class. As learning tools, they used their smartphones to see some videos of native speakers' expressions anytime and anywhere. The videos related to speaking issues on offering something, making a suggestion, and giving an opinion. The teaching materials were delivered online and offline. To do this, teachers used computer technology with internet access to provide information, speaking material, videos, and learning materials for students in the blended learning model.

In this study, researchers made the teaching-learning process more communicative, contextual, attractive, and colorful in blended learning contexts. Here, researchers used google classroom as the online platform for blended learning. The novelty of this study is seen from using blended learning using the google classroom platform to teach speaking skills. Therefore, the problem of this study was in which extend the effect of the blended learning model on the English-speaking skills for senior high school level. Two research questions were formulated in this study. Both are "is there an effect of blended learning on the English-speaking skills of for senior high school students? And Are there differences in the level of English-speaking skills after treating them using the blended learning model?

\section{Related Studies about Blended Learning}

The researcher has found several resources that explain and clarify blended learning, such as what Ginaya (2018) states that blended learning is used as an alternative technique or activities in English class. The teacher should be active in facilitating learning by applying online activities so that the activities can encourage students' critical thinking skills, such as comparing, classifying, inducing, deducing, analyzing errors, constructing support, and abstraction analyzing perspectives. The teacher's creativity in designing fun and dynamic communicative activities will stimulate their learning interest and motivation. In addition, Pramila (2019) proves that blended learning can experience remarkable progress in using the English language.

According to Brew (as cited in Sofiana, 2015), blended learning integrates online and face-to-face learning to produce a more effective learning experience. With Blended Learning, teachers can take advantage of the learning resources available online in face-to-face learning to attract students' attention and help them become more active and effective learners. In line with Brew, Sofiana (2015) argues that blended learning is a flexible learning approach that combines face-to-face learning activities with online learning that allows students to exchange feedback and responses together. It can be done in four specific areas, namely, learner feedback, learner strategies, assessment alternatives either directly or indirectly.

Marsh (2012) identified several advantages of blended learning: providing a more individualized learning experience, providing more personal learning support, supporting and encouraging independent and collaborative learning, increasing student involvement in learning, accommodating various learning styles, providing a place to practice target language outside the classroom, reduce stress in practicing the target language, provide flexible learning, anytime or anywhere, to meet the needs of learners, and help students develop skills. 


\section{RESEARCH METHOD \\ Research Design}

This research uses quasi-experimental (quasi-experimental). This study's design is a preexperimental design with using one group pretest and posttest design. This study's dependent variable is the blended learning model, while the independent variable is speaking skills. The instrument used was an oral test with a Likert scale of 0-4. The students' scores of speaking in the pre- test and posttest were compared for both groups in order to determine whether there were significant differences between the groups in relation to the treatment. The populations of this study were the students of SMA N 2 Patra Nusa. The sample was the eleventh-grade students consisting of 25 students of the eleventh-grade class. The research sample was selected based on the purposive sampling technique. The research design of this study can be illustrated in Table 1.

Table 1

Research Design

\begin{tabular}{lll}
\hline Pretest & Experiment & Posttest \\
\hline O1 & $\mathrm{X} 1$ & $\mathrm{O} 2$ \\
\hline
\end{tabular}

Information:

$\mathrm{X} 1=$ Using blended learning

$\mathrm{O} 1=$ Pretest Observation in model class before blended Learning

$\mathrm{O} 2=$ Posttest observation in the model class after blended learning

\section{Instruments}

The instruments used in this study were observation and test. The observation guidelines used in this study are the observation guidelines made by students during the learning of speaking skills using blended learning. At the test, the researcher used an instrument to record the students' performances during the action given, such as talking about offering/ suggestion, giving an opinion, and inviting someone. There were two kinds of tests used in this research, such as pretest (Test 1) for the preliminary observation in speaking, posttest (Test 2) after the treatment for the final performance in speaking. The speaking tests in pretest and posttest were scored based on oral proficiency scoring categories (Brown and Abeywickrama, 2004). The description of the students' speaking scores was a modified form of scale $0-100$, which included five speaking components, namely grammar, vocabulary, comprehension, fluency, and pronunciation.

Table 2

The criterion of speaking scores

\begin{tabular}{lll}
\hline No & The Indicator of Assessments & Scores \\
\hline 1 & Grammar & $0-4$ \\
\hline 2 & Vocabulary & $0-4$ \\
\hline 3 & Comprehension & $0-4$ \\
\hline 4 & Fluency & $0-4$ \\
\hline 5 & Pronunciation & $0-4$ \\
\hline
\end{tabular}

\section{Data Analysis}

The data were analyzed quantitatively. It was based on the speaking performances during the instructions. The students' scores in the preliminary observation (pretest) were analyzed using the SPSS-17.0 program. A t-test was computed to ensure that there was no difference 
between pretest and posttest in the experimental. Simultaneously, the students' scores in the posttest (test 2) were again analyzed in the SPSS. Then, paired sample t-tests were computed for both groups' results to investigate the differences between the pretest and posttest in each group.

\section{RESEARCH FINDINGS AND DISCUSSION \\ Research Findings}

Before the testing of hypothesis using the t test, the result of data about an effect of blended learning on the English-speaking skills especially the test data normality as a t-test requirement. Based on the normality test the data was obtained that the data on student learning outcomes students speaking skill using Blended Learning model with Google Classroom distributed media with unnormal (Table 2). This is shown from test results using the Kolmogorov-Smirnov where Sig of pretest $(0.009)<\alpha,(0.05)$ not distributed with normal as posttest $(0,008)<\alpha(0,005)$ not distributed with normal, that is why the researcher cannot use t-test but used Wilcoxon test.

Table 3

Test of Normality

\begin{tabular}{|c|c|c|c|c|c|c|}
\hline \multicolumn{4}{|c|}{$\begin{array}{l}\text { Kolmogorov - } \\
\text { Smirnov }\end{array}$} & \multicolumn{3}{|c|}{ Shapiro- Wilk } \\
\hline & Statistic & Df & Sig & Statistic & df & Sig \\
\hline Pretest & , 179 & 25 & ,039 & ,886 & 25 & ,009 \\
\hline Posttest & ,202 & 25 & 010 &, 882 & 25 &, 008 \\
\hline
\end{tabular}

Tabel 4

Paired Sampel Statistic dan Corelation

\begin{tabular}{lccccc}
\hline & Experiment & Mean & N & Std. Deviation & Sig \\
\hline Pretest & 77,04 & 25 & 4,843 &, 009 \\
\hline Post-test & 85,92 & 25 & 5,887 &, 008 \\
\hline
\end{tabular}

Table 4 showedthat sig. 2-tailed $=0.000<\alpha(0.05)$, it means reject H0. In conclusion, the mean pretest and posttest scores differ significantly, or there is an effect of blended learning on enhancing students speaking skill of SMA N 2 Patranusa.

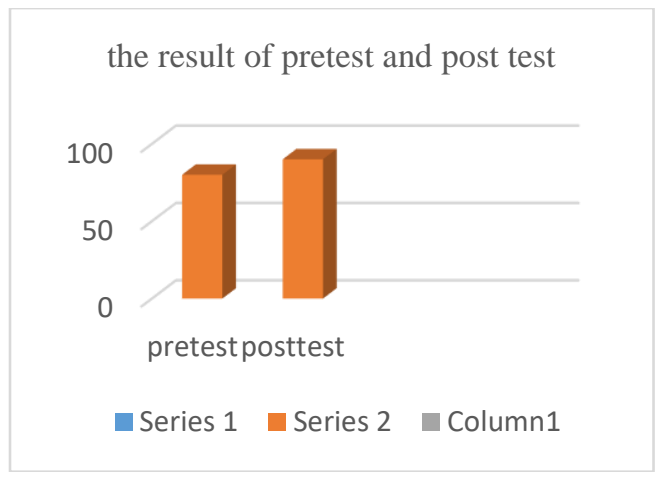

Figure 1. the result of pretest and posttest 
Figure 1 showed that the mean score in the pretest was lower than in the posttest. However, it can be concluded that there were highly significant differences between the conventional teaching model and the blended learning model. The application of this learning is in line with the philosophical essence of e-learning that e-learning itself doesn't mean to replace the conventional learning model totally in the class. Still, it can strengthen the model of learning through diversifying the learning content and utilizing educational technology. The results of data analysis showed a significant enhancement of speaking skills between pretest and posttest using the Blended Learning model with Google Classroom media to enhance students' speaking skills.

\section{Discussion}

This study aimed to find out the effect of blending learning on students' speaking skills at the eleventh-grade students of senior high schools. It was involved 25 students to be treated using blended learning. The platform applied was google classroom. According to Sukmawati and Nensia (2019), google classroom in the blended instruction is to offer a platform of blending learning to simplify producing learning tasks and creating scores for students in a paperless way. In doing so, the teaching materials in this study were designed to help students practice speaking skills. The speaking skills are addressed on developing vocabulary, fluency, pronunciation, and accuracy (Aprianoto \& Haerazi, 2019). The students are divided into some groups to practice their speaking skills online and offline.

This study is started from some preparations. Researchers are concerned about enhancing the students' speaking skills on the English subject through blended learning in the experimental group in the planning step. For this purpose, an instructional planning or teachinglearning scenario and instruments were prepared. Before the students worked online, face-toface instruction on the application of the treatment was presented. The teacher used three teaching topics: offering something, giving opinion, and inviting someone (Tomlinson, 2019). The researcher chooses that topic based on an appropriate curriculum from eleven grade students to see the syllabus at that class.

At the face-to-face learning, the teacher explains offering, how to offer/suggest people and asking the students to make the roleplay with some topics. While when the e-learning process, the teacher using the media google classroom. At that media, the students are really enthusiastic because the teacher attaches some video of teaching speaking on the English subject, using the topics giving opinion and inviting someone. At the first online meeting, the teacher posted material about giving an idea. The teacher also used video recording to record the provided material. It is in line with Serdar-Tuluce and Cecen (2019), who claim that videos help students imitate how native speakers express their ideas in English correctly. Then, the teacher explained how to create a conversation using those expressions then sent the explanation about giving the opinion via YouTube channel to the students. After the teacher opens the session of asking and answering questions related to the topic, the teacher asks the students to create a conversation related to the topics that were already given.

At the second online meeting, the teacher posted the material on how to invite someone. The teacher explained the kinds of expression used at the dialog and then shared video from the native attached from YouTube to google classroom. It allows students to analyze language features such as vocabulary and sentence structure (Anas, 2019). The students really interested followed the class their assignment can prove it at the video recording, any improvement at the vocabulary, grammar, performance, pronunciation, intention, and fluency. It can be seen based on the posttest given by the teacher at the last online meeting using google classroom media.

In relation to the classroom interaction, the students tried to interact maximally in order to get a better solution for the problems. These activities and practices were intended to stimulate their speaking creativity (Haerazi, Vikasari, \& Prayati, 2019). So here, it could be 
seen that the students' participation in the teaching-learning process used blended learning improved well. It also meant that the students enjoyed the class and were pushed to work hard to maximize their potential to use their English. Consequently, their speaking skill was enhanced significantly as the result of the posttest showed it.

\section{CONCLUSION}

This study aimed to investigate the effect of blended learning on enhancing students' speaking skills and the extent of differences of those after giving treatments using blended learning at the senior high school's eleventh-grade students. In teaching speaking skills, students are involved in online and offline learning activities. They are provided some speaking videos coming from English native speakers. They are asked to imitate any kind of language features and practice those in a conversation. Also, they are asked to note some difficult vocabulary while analyzing the video. Therefore, this study can be concluded that blended learning has a positive effect on students' speaking skills.

\section{ACKNOWLEDGEMENT}

The researcher realized that the accomplishment of this article would not run well without any help from the others. Therefore, here she wishes to give her sincerest gratitude and appreciation to her dean and colleagues who have the support and valuable comments in any part of this manuscript. Finally, this article is still far from being perfect. Hence, any criticisms or suggestions from the readers and users are welcome to the researcher to improve. At the same time, the researcher hopes that this article can be useful for other writers, teachers, and students.

\section{REFERENCES}

Abe, E. (2013). Communicative language teaching in Japan: Current practices and future prospects. English Today, 29(2), 46-53. https://doi.org/10.1017/S0266078413000163

Anas, I. (2019). Behind the scene: Student-created video as a meaning-making process to promote student active learning. Teaching English with Technology, 19(4), 37-56.

Aprianoto, \& Haerazi (2019). Development and assessment of an interculture-based instrument model in the teaching of speaking skills. Universal Journal of Educational Research 7(12) pp. 2796-2805. DOI: https://doi.org/10.13189/ujer.2019.071230

Ardiansyah, A. (2020). Improving students' speaking skills through the use of video-based scientific approach. Journal of Languages and Language Teaching, 8(3), 222-236. doi: https://doi.org/10.33394/jollt.v8i3.2734

Arikunto, S., \& Supardi. (2012). Penelitian Tindakan Kelas . Jakarta : Bumi Aksara

Brown, H. D., \& Abeywickrama, P. (2004). Language assessment. Principles and Classroom Practices. White Plains, NY: Pearson Education

Carman, J. M. (2005). Blended Learning Design: Five Key Ingredients. Blended Learning Design: 5 Key Ingredients. https://doi.org/10.1109/CSSE.2008.198

Ginaya. G, Rezeki. M., Astuti, S. (2018). The Effects of Blended Learning to Students' Speaking Ability: A Study of Utilizing Technology to Strengthen the Conventional Instruction. IJLLC (International Journal of Linguistics, Literature and Culture),4(3), 114. http://dx.doi.org/10.21744/ijllc.v0i0.000

Garrison, D. R. (2011). E-learning in the 21st century: A framework for research and practice. Taylor \& Francis.

Haerazi, H., May Vikasari, R., \& Prayati, Z. (2019). The use of scientific-based approach in ELT class to improve students' achievement and classroom interaction. Register Journal, 12(2), 157-180. https://doi.org/10.18326/rgt.v12i2.157-180 
Hengki, T,P (2014). Implementasi Model Pembelajaran Blended Learning Untuk Meningkatkan Aktifitas Belajar Multimedia Siswa Kelas XI Multimedia 1 SMK Muhammadiah 2 Klaten Utara Tahun Ajaran 2013/2014. Yogyakarta (ID):UNY

Hoesny, M., Cahyani, H., \& Aziz, I. (2020). The use of edmodo in ESP classroom: A study on students' perception and classroom activities. Journal of Languages and Language Teaching, 8(3), 237-250. doi: https://doi.org/10.33394/jollt.v8i3.2602

Limbong, E. (2017). Designing and Developing Supplemental Technology of PACI Model Materials through Blended Learning Methods. In Celt: A Journal of Culture, English Language Teaching \& Literature (Vol. 16, Issue 2). https://doi.org/10.24167/celt.v16i2.771

Pramila, K \& Thomas, J (2019). Impact of Blended Learning on the Speaking Skills of English as a Foreign Language (EFL) Learners at Sohar University. Anthropologist, 35(1-3), 47 56. http://DOI: 10.31901/24566802.2019/35.1-3.2039

Maryam, S. (2020). Utilizing communicative language games to improve students' speaking ability. Journal of Languages and Language Teaching, 8(3), 251-263. doi: https://doi.org/10.33394/jollt.v8i3.2733

Qariah, M., Munoto., \& Lilik, A. (2017). Pengaruh Model Pembelajaran Blended Learning Dan Motivasi Belajar Terhadap Hasil Belajar Siswa. Jurnal Penelitian Ilmu Pendidikan. 2(10), $97-110$

Sarah, B (2015). Efektivitas Model Blended Learning Terhadap Motivasi Dan Tingkat Pemahaman Mahasiswa Mata Kuliah Algoritma Dan Pemrograman. Jurnal Pendidikan Vocasi.1(5),74-87

Serdar Tülüce, H., \& Çeçen, S. (2018). The use of video in microteaching: affordances and constraints. ELT Journal, 72(1), 73-82. https://doi.org/10.1093/elt/ccx028

Sharma, P. (2010). Blended learning. ELT Journal, 64(4), 456-458. https://doi.org/10.1093/elt/ccq043

Sofiana, N (2015). Implementasi Blended Learning Pada Mata Kuliah Extensive Listening. Jurnal Tarbawi .1(12), 59-70.

Sukmawati, S., \& Nensia, N. (2019). The Role of Google Classroom in ELT. International Journal for Educational and Vocational Studies, 1(2), 142-145. https://doi.org/10.29103/ijevs.v1i2.1526

Sumarsono, D., Muliani, M., \& Bagis, A. (2020). The forecasting power of task-based language teaching and self-efficacy on students' speaking performance. Journal of Languages and Language Teaching, 8(4), 412-421. doi: https://doi.org/10.33394/jollt.v8i4.2848

Suryaningsih. 2017. Pengaruh Metode Pembelajaran Show and Tell Terhadap Keterampilan Berbicara Siswa Kelas IV Tema 6 Daerah Tempat TinggalKu Di SD Muhammadiah Condongcatur. Yogyakarta (ID): UIN Sunankalijaga Yogyakarta.

Tomlinson, B. (2019). Blended Learning: The Future of ELT? . The TESOL Encyclopedia of English Language Teaching, 1-7.https://doi.org/10.1002/9781118784235.eelt0941.pub2

Zilka, G. C., Rahimi, I. D., \& Cohen, R. (2019). Sense of Challenge, Threat, Self-Efficacy, and Motivation of Students Learning in Virtual and Blended Courses. American Journal of Distance Education, 33(1), 2-15. https://doi.org/10.1080/08923647.2019.1554990

Wahyuni. S, Elfita F. (2018). Pengaruh Blended Learning Model dan Sikap Berbahasa Terhadap Kemampuan Menulis Bahasa Inggris Siswa Sekolah Menengah Negeri di Pekan Baru. Jurnal GERAM.1(6),1-9 